\title{
Falhas e sustentabilidade do sistema migratório laboral temporário*
}

\author{
Graziano Battistella**
}

Sistemas migratórios são definidos por políticas migratórias prevalentes que os caracterizam. Na realidade, todos os sistemas incluem políticas que visam o estabelecimento permanente, de longa duração e temporário de migrantes. A prevalência de uma política sobre outras caracteriza o sistema e revela a principal atitude política de uma nação, ou um grupo de nações, em relação aos migrantes. Nesse aspecto, continuamos falando de sistemas permanente, temporário e de longa duração de migração.

Em termos gerais, países tradicionais de imigração buscam políticas de migração permanente e concedem, anualmente, certo número de vistos para a residência permanente. Esses países são: Estados Unidos, Canadá, Austrália e Nova Zelândia. Os vistos permanentes geralmente são agrupados em três categorias (motivos familiares, econômicos ou humanitários). Os procedimentos para concessão de vistos, os requerimentos para obtê-los e a distribuição desses entre as três categorias citadas variam de um país para outro, mas o objetivo comum é permitir que imigrantes residam em seus territórios.

Outros países são relutantes em conceder residência permanente a imigrantes. Suas políticas visam admitir trabalhadores por um curto período de tempo, sem possibilidade de residência de longa duração para seu estabelecimento permanente. Os países do Golfo, do Leste e do Sudeste da Ásia adotaram políticas desse tipo, mostrando que estão abertos a receber a contribuição de trabalhadores imigrantes, mas não muito propícios a deixar que a migração mude as características étnicas de sua sociedade.

As migrações de longa duração caracterizam os países da União Europeia. Eles admitem trabalhadores migrantes temporariamente. No entanto, sua estadia pode ser renovada e então, finalmente, podem receber um cartão de residência permitindo que fiquem indefinidamente no país.

Como dito anteriormente, políticas prevalentes não impedem que outras sejam adotadas concomitantemente. Na verdade, todos os países têm algum modelo de migração temporária. Esse tipo de movimento tem recebido muita

\footnotetext{
* Traduzido do original "Flaws and sustainability of temporary labor migration" por Karina Moysés Pain. Revisão técnica: José Carlos Pereira

** Diretor do Centro de Migração Scalabrini - Roma - Itália
} 
atenção nos últimos 15 anos, e novas modalidades de migração temporária são experimentadas ou aplicadas. Esse novo interesse lança novas questões sobre as vantagens e desvantagens da migração laboral, sua sustentabilidade e a possibilidade de uma abordagem da migração temporária baseada em direitos. Esse artigo irá examinar experiências históricas de migração temporária e sua recente volta. Também analisará esse movimento na Ásia, concernindo seus quatro modelos diferentes e incluindo suas vantagens e desvantagens. 0 artigo será concluído com uma mostra de elementos para uma abordagem da questão migratória baseada em direitos.

\section{Algumas experiências históricas de migração temporária e sua volta}

Os Estados Unidos da América - EUA, país onde tradicionalmente os projetos migratórios visam o estabelecimento permanente, tiveram uma experiência com migração temporária durante 20 anos, desde o começo da 2a Guerra Mundial até 1964. A participação de jovens e adultos nos diversos setores da guerra deixou o país sem mão de obra na área rural, que então buscou trabalhadores mexicanos. Em agosto de 1942, os governos dos EUA e do México firmaram um acordo conhecido como bracero program. Trabalhadores mexicanos deixavam suas terras para trabalhar nos EUA colhendo tomates e pepinos, desbastando beterraba-sacarina com uma cansativa enxada curta - que se tornou um símbolo de trabalho árduo - e colhendo algodão.

Os trabalhadores tinham que cuidar das suas permissões de trabalho e voltar para o México ao final do contrato (que durava de quatro semanas até seis meses). Custo de vida, transporte de ida e de retorno deveriam ser garantidos através de títulos bancários; a discriminação e um salário reduzido eram proibidos, no entanto esses incidentes ocorriam e alguns processos chegaram aos tribunais ainda nos anos 1990. Porém, nunca chegaram às famílias dos trabalhadores no México. Também se instituiu um bracero program para as linhas férreas, como modo de conseguir trabalhadores baratos, mas esse acabou com o final da guerra em 1945.

O programa na agricultura continuou depois da guerra, pois esse setor alegou que havia falta de mão de obra, embora críticos afirmassem que havia trabalhadores locais disponíveis e que eram os empregadores que não estavam dispostos a lhes pagar salários adequados. Essa continuidade levou à imigração irregular nos EUA, favorecida por cadeias sociais e um procedimento regulatório que não impunha punições aos fazendeiros contratadores de trabalhadores irregulares. 0 acordo terminou em 1964 (depois de 22 anos e da participação de 4,6 milhões de trabalhadores mexicanos, alguns recorrentes) por se tornar inviável devido à mecanização da agricultura, e também porque gerava competição injusta com trabalhadores locais, além de muita crítica concernente à violações de direitos humanos inerentes ao programa (Martin, 2003). 
Na Europa houve falta de trabalhadores depois da Segunda Guerra Mundial para a reconstrução da região (embora se argumentasse que a migração não servia para providenciar mais mão de obra - a taxa de desemprego na Alemanha em 1955 era de 5.1\% - mas sim para substituir os trabalhadores locais, que buscavam condições melhores de trabalho (Bade, 2003, p. 227). As economias Ocidental e do norte Europeu, que já tinham uma tradição de imigração pré-guerra, empregavam, como fonte de mão de obra adicional, trabalhadores de países da Europa mediterrânea (Itália, Espanha, Portugal, Grécia e mais tarde lugoslávia). A França, que contava com uma grande base colonial, aceitava imigrantes da região de Magreb (Marrocos, Algéria [Argélia] e Tunísia). A Alemanha, entretanto, além da Itália e do sul Europeu escolheu a Tunísia como principal fonte de trabalhadores.

A modalidade de recrutamento laboral era ancorada em acordos bilaterais, baseados no ímpeto da recomendação 86 da OIT - Organização Internacional do Trabalho, companheira da Convenção 97 sobre os Trabalhadores Migrantes - Revisada - (OIT, 1949), que contém um acordo modelo para os países seguirem. A Alemanha assinou oito acordos desse tipo entre 1955 (acordo com a Itália) e 1968 (acordo com Portugal), (Bobeva and Garson, 2004, p. 13). Além da Alemanha, a França e a Suíça eram grandes países de importação de mão de obra, apesar de seus planos funcionarem de modos diferentes (Plewa and Miller, 2005, p. 61). A França desenhou um sistema de recrutamento anônimo e nominativo, mas comumente acabava regularizando migrantes não autorizados contratados por empregadores que evitavam o sistema. A Suíça focou em trabalhadores sazonais que deveriam regressar aos seus países anualmente. Mas, teve que renegociar devido às condições inaceitáveis de migração laboral, constituindo assim as premissas para residência de longo termo. A Alemanha recrutava força laboral imigrante através do envolvimento direto do Ministério do Trabalho no processo de recrutamento. Como os trabalhadores eram contratados por um curto período de tempo e tinham que retornar ao seu país de origem, eram chamados na Alemanha de "trabalhadores visitantes". No entanto, nem todos os trabalhadores rotacionais retornavam ao seu país e então se estabeleciam no local com membros familiares.

O programa do trabalhador visitante acabou em 1973-1974 por diversos motivos. Um dos mais citados foi a crise econômica que acompanhou o aumento dos custos de energia causado pela Guerra do Golfo. Entretanto, mesmo antes da crise, o envolvimento de trabalhadores imigrantes em greves e protestos na França, e a violência na Alemanha entre trabalhadores turcos e alemães tiveram grande peso nesse término (Plewa and Miller, 2005, p. 64). Bade (2003) diz qua a crise energética foi só um último argumento para o fechamento do programa, que estava sendo questionado pela tendência de estabelecimento permanente dos trabalhadores (dado que a Carta Social Europeia (art. 19.6) garantia reunificação familiar) e a incongruência entre as políticas de imigração e de integração. Políticas restritivas de integração eram 
direcionadas a migrantes norte-africanos na França e aos turcos na Alemanha. Castles (2006, p. 743) também argumenta que os seguintes motivos levaram ao fim do sistema de migração temporária:

- a ligação entre o projeto de migração e um ciclo de vida: quando jovem ele é considerado temporário, mas com o tempo se torna permanente;

- a escolha de se ficar no país de imigração em tempos de crise, pois parece mais favorável do que retornar ao seu país de origem;

- a inserção do imigrante no sistema de benefícios do país receptor também serviu de incentivo para o estabelecimento;

- a dificuldade de se expulsar um imigrante residente legal em uma democracia liberal, onde os direitos do povo são protegidos pelas cortes;

- a coalizão de organizações pró-imigração que se uniu aos partidos liberais para coibir iniciativas anti-imigrantes.

O motivo mais importante para o fim do programa de trabalhador visitante foi a falha no próprio conceito: trabalhadores temporários estavam suprindo uma necessidade permanente de mão de obra. Finalmente, os empregadores constataram que empregados rotacionais não eram rentáveis.

O fim do trabalhador visitante na Europa não acabou com a entrada de migrantes, que continuaram a ir para a França, Alemanha e outros países como membros de família de migrantes residentes ou trabalhadores sazonais. Embora esses familiares tenham obtido permissão para trabalhar, a necessidade de trabalhadores imigrantes permaneceu. Consequentemente, um grupo de pequenos programas de migração foi executado em diversos países (Plewa and Miller, 2005). Foram permitidos imigrantes poloneses e turcos na Dinamarca para trabalharem na agricultura nos anos 1980. Migrantes poloneses europeus orientais também foram tolerados na Alemanha no mesmo período. Mas, pequenos programas específicos foram implementados no final da década de 1990 visando trabalhadores sazonais - aqueles ligados a projetos, estagiários, migrantes pendulares e outros. No Reino Unido trabalhadores de férias (jovens entre 17 e 27 anos, permitidos a trabalhar por no máximo dois anos) chegaram a 4.000 no ano de 2004 e trabalhadores sazonais da Polônia e Ucrânia foram admitidos.

A substituição de grandes programas por pequenos programas de migração também foi acompanhada pelo maior fluxo de trabalhadores migrantes nos Estados do sul da Europa. Essas tradicionais regiões de origem de migração tornaram-se destinos dos principais fluxos migratórios no continente, começando pela Itália nos anos 1980, seguida pela Espanha e, em números menores, Grécia e Portugal. Em geral, a imigração nesses países tem ocorrido irregularmente de modo que foram implementados diversos programas de regularização (Levinson, 2005). 
O retorno da migração temporária foi confirmado na conclusão da Comissão Mundial sobre as Migrações Internacionais que, baseada no princípio de que a migração deveria ser uma escolha e não uma necessidade, declarou que "os Estados e o setor privado deveriam considerar a opção de introduzir um programa de migração temporária cuidadosamente desenhado como modo de tratar das necessidades econômicas do país de origem e destino" (GCIM - Global Commission on International Migration, 2005,79).

Dentre os diversos modos de se organizar a migração temporária, a migração sazonal tem uma longa tradição. O Programa Canadense de Trabalhadores Agricultores Sazonais (SAWP, em inglês), particularmente em cooperação com o México, envolve cerca de 20.000 migrantes por ano e existe há quatro decádas. É baseado no tratamento igual ao dos trabalhadores canadenses, e também na assistência do governo mexicano para garantir a disponibilidade da mão de obra e seu bem-estar.

Recentemente a Nova Zelândia implementou o plano de Empregadores Sazonais Reconhecidos (RSEs), que emprega cerca de 8.000 migrantes das ilhas do pacífico por um período de sete meses. A União Europeia adotou, em fevereiro de 2014, uma diretiva sobre trabalhadores sazonais para regular esse fenômeno que tem ocorrido nos últimos anos. A Alemanha libera em torno de 300.000 permissões de trabalho, todo ano, para esses trabalhadores, cuja maior parte vem da Polônia, Bulgária e România, que são empregados no setor agrícola e em atividades ligadas ao turismo e lazer como hospedagem e carnaval. A diretiva requer que os trabalhadores mantenham suas residências no país de origem; os governos devem decidir o tempo de trabalho (entre cinco e nove meses); devem ser garantidos aos trabalhadores padrões de acomodação, saúde e segurança e deve haver um contrato de trabalho; deve ser garantido o mesmo padrão de tratamento que os trabalhadores locais recebem e trabalhadores migrantes podem trocar de empregador uma vez durante o contrato. Criticada pela Associação Europeia pela Defesa dos Direitos Humanos (AEDH) por não proteger suficientemente os direitos dos trabalhadores, a diretiva indica a intenção dos países da União Europeia de usufruir mais de trabalhadores temporários.

Em setores como manufatura, serviços, construção, agricultura, hotelaria, atendimento, enfermagem, ensino e alimentação, empregadores com necessidade de mão de obra extra costumam utilizar Agências de Trabalho Temporário (TAW, em inglês). Os trabalhadores são contratados por agências e não diretamente por pessoas ou empresas para quem efetivamente trabalharão. Esse processo é bem popular nos EUA, Japão e Europa. As Agências contratadoras cooperam com agências de recrutamento nos países de origem e costumam oferecer diversos serviços aos trabalhadores (acomodação, empréstimos...), com possíveis abusos nessas práticas (McLoughlin and Münz, 2011, p. 45).

$O$ interesse na migração temporária também se intensificou com a introdução do conceito de "migração circular". A ideia ganhou apoio pois, 
teoricamente, promete um ganho triplo, beneficiando o país de origem, o de destino e o migrante. Na verdade, por um lado, o conceito parece ser só outro modo de se falar de migração temporária, que é cíclica, dado que a natureza do contrato não permite a conclusão da projeção migratória. Por outro, em sua implementação ideal, a constante mudança de país deixa implícita uma liberdade de movimentação normalmente dada somente à trabalhadores qualificados, que podem não estar tão interessados nesse movimento circular. Ainda assim, em 2007 a Comissão Europeia emitiu um Comunicado, no qual sugeriu a possibilidade de concessão de vistos de residência/trabalho plurianuais para trabalhadores sazonais. No entanto, parece que a verdadeira intenção da migração circular é garantir que migrantes temporários não fiquem em países da União Europeia (McLoughlin and Münz, 2011, p. 25). Nesse propósito, falar de migração circular gerenciada é retomar a ideia de migração temporária.

A migração temporária cresceu também em países tradicionais de imigração permanente como os EUA, Canadá e Austrália. Nos EUA, além da imigração permanente, migrantes temporários são admitidos em diferentes planos. Houve 1.900.582 trabalhadores temporários e estagiários aceitos em 2012 no país, dos quais 473.015 eram altamente qualificados (Visto HB1) e 183.860 eram trabalhadores rurais (H2A) (EUA, 2012). No mesmo ano, 491.547 trabalhadores temporários entraram no Canadá - a maioria qualificados ou altamente qualificados (CANADA, 2013). Em 2013, os trabalhadores de período de férias chegaram a 178.980 pessoas na Austrália. Dessas, 169.070 eram trabalhadores qualificados (subclasse 457) (DIBP, 2013). As ocupações mais altas da subclasse 457 eram profissionai3s da saúde, assistentes sociais, cozinheiros e trabalhadores na área de construção.

\section{O crescimento da migração laboral na Ásia}

Ao mesmo tempo em que o sistema do "trabalhador visitante" acabou na Europa, ele se vitalizou na Ásia ocidental. Os países do Golfo, que foram os que mais tiraram proveito do aumento do custo do petróleo depois da guerra na região, fizeram altos investimentos em projetos de infraestrutura. O gerenciamento dos projetos ficou nas mãos de empresas americanas, europeias e asiáticas que contratavam mão de obra de países vizinhos, primeiramente na península arábica (lêmem, Egito, Sudão, Jordânia e Palestina) e depois no sul e sudeste asiático. A mudança de trabalhadores árabes para asiáticos foi impulsionada pela vontade de se evitar ideologias pan-arábicas, que incentivavam os trabalhadores a se estabelecerem com suas famílias (Kapiszewski, 2006). A primeira onda de mão de obra se encarregou da infraestrutura e foi seguida pela segunda onda dedicada a manutenção e serviços. Finalmente, a economia do Oriente Médio ficou, e continua até hoje, dependente do trabalho de migrantes, especialmente no setor privado. 
Além dos países do Golfo, outras nações asiáticas utilizaram esse tipo de mão de obra. Existem semelhanças e diferenças nos sistemas asiáticos e assim podemos falar de cinco modelos de migração laboral temporária.

\section{a. O sistema kafala nos países do Golfo}

O sistema adotado nos países do Golfo foi desenhado para prover habilidades e trabalhos não supridos pela mão de obra local, ao mesmo tempo em que excluía a possibilidade de integração e mudança étnica na população local. Com exceção da Arábia Saudita, os países do Golfo têm uma pequena população. Um alto número de imigrantes poderia mudar facilmente as características locais caso fosse permitido que ficassem. De fato, a porcentagem de imigrantes na população é particularmente alta nos Emirados Árabes Unidos, sendo de $83.7 \%$ em 2013, de acordo com a UN-DESA (2013), Qatar (73.8\%), Kuwait (60.2\%) e Bahrain (50.7\%), Consequentemente, a maior parte dos trabalhadores imigrantes, principalmente os profissionalmente menos qualificados, ficam em campos de trabalho e não se integram à vida social local.

Para garantir a mão de obra e evitar integração, o sistema de migração laboral do Golfo foi organizado com base em três características que desde então se tornaram modelo para o todo o continente: os migrantes são contratados por agências de recrutamento e emprego que operam nos países de origem e destino; os migrantes são contratados com acordos de curto prazo (no máximo dois anos); o contrato pode ser renovado e pode-se fazer um novo contrato, mas só após o trabalhador retornar ao país de origem.

O que é específico dos países do Golfo é o sistema kafala, no qual a permissão para entrar nesses países é dada pelo Ministério do Trabalho para empregadores ou agentes (kafeels) que contratam migrantes em agências de recrutamento nos países de origem. Uma vez no país, o trabalhador depende do kafeel, que é o responsável pelo seu emprego, alojamento, seguro médico e outras licenças. Dado que o kafeel age como empregador ou agente, ele determina as condições do emprego, que podem não corresponder ao contrato assinado antes da viagem do migrante. Como o motivo para ficar no país depende completamente do emprego arranjado, o migrante fica dependente do kafeel. Essa dependência é particularmente problemática no caso do contratado querer romper o acordo feito, posto que isso não é possível sem autorização do kafeel.

Muitas irregularidades estão ligadas ao sistema kafala, no qual kafeels admitem mais empregados do que empregos disponíveis, transferem migrantes a outros empregadores com condições de trabalho diferentes das combinadas e cobram dos migrantes despesas pelas quais o empregador deveria ser responsável. Foram prometidas reformas no sistema kafala, mas sem resultados significantes. Talvez a medida mais recente tenha sido a decisão, em 2013, da Arábia Saudita de credenciar 10 mega empresas de 
recrutamento para a importação de mão de obra (SAUDI ARABIA, 2013). As mega agências são responsáveis pela contratação, emprego e condições dos trabalhadores. A intenção é reduzir o número de kafeels e, consequentemente, potenciais irregularidades cometidas contra os migrantes. No entanto, ainda existem incertezas, já que as agências podem ser os empregadores, ou podem colocar os migrantes com um empregador e depois transferi-los para outro, sem assegurar que as condições originais do contrato sejam respeitadas.

\section{b. As taxas e sistemas de cotas em Cingapura}

Cingapura utilizou trabalho de migrantes nos primeiros estágios de sua construção nacional. Depois da sua separação da Malásia em 1965 e seu rápido desenvolvimento econômico, Cingapura trouxe seus primeiros migrantes da Malásia e depois expandiu a sua demanda para a República Popular da China e outros países do sul e sudeste asiático. $O$ governo do país não divulga estatísticas sobre trabalhadores imigrantes, pois há temor de que a divulgação possa perturbar a percepção de um balanço étnico na população, que consiste majoritariamente de chineses (cerca de 75 por cento), malaios e indianos. No entanto, a população nascida fora do país tem crescido nos últimos anos e chegou a $38 \%$ ao final do ano de 2012, de acordo com o Ministério do Trabalho. Mais de meio-milhão são residentes permanentes, enquanto os demais são não-residente.

As políticas migratórias de Cingapura sempre foram feitas para servir ao crescimento econômico do país, particularmente atraindo trabalhadores qualificados enquanto controla o fluxo de trabalhadores não qualificados para não diminuírem o ritmo de produção. Foram utilizados dois instrumentos para esse controle: uma cota fixa de trabalhadores migrantes em cada setor e uma taxa que o empregador têm que pagar para cada um desses trabalhadores: quanto mais baixa a qualificação profissional do empregado, mais alto o valor do imposto.

Apesar dessas medidas, a mão de obra imigrante cresceu 3,3\% a cada ano entre 1980 e 2010, de acordo com o National Population Singapore and Talent Division 2013 (Singapore, 2013a). Trabalhadores de construção civil (319.100 ao final de 2013) e trabalhadores domésticos (214.500) são grupos de destaque na contratação de imigrantes.

O Livro Branco da População ${ }^{1}$ de 2013 (SINGAPORE, 2013) motivou o uso de mão de obra imigrantes para satisfazer necessidades sociais e de desenvolvimento (particularmente no cuidado de idosos), a fim de substituir trabalhadores locais que se moviam para postos de trabalho mais qualificados, para ajudar a despontar setores emergentes e dar flexibilidade ao mercado de trabalho.

\section{c. Uso de migração irregular na Malásia e Tailândia}

A Malásia e a Tailândia eram países de origem de emigração, mas nos anos 1980 e 1990 se tornaram países de imigração. Tailândia e Malásia fazem 
fronteiras com importantes países de origem, como Myanmar e Indonésia, e assim se tornaram países de destino para a migração irregular.

A imigração para a Malásia começou de forma irregular vinda da Indonésia nos anos 1970 e foi formalizada nos anos 1980 com um acordo bilateral. Inicialmente era o setor agrícola em particular que precisava de trabalhadores, pois os trabalhadores locais estavam abandonando o campo. Mais tarde outros setores começaram a contratar imigrantes, como a construção e manufatura. Ao final do ano de 2012, estimava-se que 1,5 milhões de imigrantes tinham emprego legal na Malásia. Cerca de $50 \%$ da Indonésia e Bangladesh, Nepal, Myanmar, Índia e Vietnã estavam expressivamente representados. A política de intervenção na Malásia seguia o ciclo econômico permitindo a entrada de trabalhadores em tempos de crescimento econômico, restringindo, repatriando em tempos de recessão.

Devido ao grande número de migrantes irregulares, diversos registros foram feitos, o último em 2012, quando se regularizou 1,3 milhões de migrantes. No entanto, como aconteceu com outras iniciativas, não se pode esperar que a migração irregular não continue. A Malásia também implementou um sistema de taxa, com o objetivo de diminuir o número de trabalhadores pouco qualificados e construir uma economia mais produtiva, mas os resultados foram menos expressivos que em Cingapura.

Nos anos 1990, a Tailândia se tornou destino de migrantes, principalmente de seus três países vizinhos: Myanmar, Camboja e Laos. Por conta da fronteira porosa com Myanmar, Camboja e Laos, e da permissividade dos oficiais de fronteira, os migrantes costumam entrar irregularmente. Quase todo ano, a Tailândia tem uma iniciativa de regularização na qual os empregadores registram os trabalhadores imigrantes que então obtêm uma permissão de trabalho. Contudo, para evitar custos de registro, menos da metade dos dois milhões de trabalhadores imigrantes são registrados. Além disso, os registros não são renovados no ano seguinte, fazendo com que os migrantes fiquem entre a regularidade e irregularidade. Para tentar organizar o status dos trabalhadores, a Tailândia fez acordos bilaterais com cada um dos três países vizinhos, mas houve pouco avanço na diminuição da irregularidade. A dificuldade da Malásia e da Tailândia na administração migratória não se resume apenas à falha de políticas na área, mas também por uma combinação de fatores geográficos (é quase impossível de se policiar fronteiras extensas) e conveniência econômica. Em alguns aspectos pode-se dizer que a migração irregular não é um desvio das políticas migratórias, mas faz parte delas, garantindo a flexibilidade no mercado laboral. A vantagem da irregularidade é que ações para se reduzir o número de migrantes irregulares não são contestadas, assim se pode expulsar rapidamente um certo número de trabalhadores. Algumas declarações referentes ao trabalho de migrantes, feitas pelo grupo militar que tomou o poder recentemente na Tailândia, levaram ao retorno de cerca de 160.000 trabalhadores irregulares para o Camboja (Cheang, 2014). 


\section{d. O sistema de corretagem de Taiwan}

Taiwan adotou formalmente uma política de migração laboral temporária em 1992. A intenção era permitir o trabalho dos migrantes e ao mesmo tempo evitar o seu enraizamento no país. Com esse objetivo os vistos eram dados para migrantes de quatro países (Malásia, Indonésia, Filipinas e Tailândia) por dois anos, extensível até um ano. Após este período, o trabalhador deveria voltar ao seu país e não poderia mais retornar a Taiwan. Esse esquema falhou rapidamente. Primeiramente, porque os migrantes achavam três anos pouco para cumprir seus projetos, e, em segundo lugar, os empregadores achavam custoso ter que constantemente treinar novos empregados. Finalmente, permitiu-se que os vistos fossem renovados por até doze anos. O número de trabalhadores migrantes em Taiwan cresceu e chegou a 489.134 ao final de 2013. O Vietnã e a Mongólia foram adicionados ao rol de países iniciais (embora não haja quase nenhum mongol trabalhando em Taiwan). A maior parte dos trabalhadores é constituída de indonésios, em geral mulheres empregadas como cuidadoras de taiwaneses idosos. Tailandeses são amplamente empregados na construção civil, enquanto filipinos e vietnamitas trabalham em fábricas de TI (tecnologia da informação). O que é característico de Taiwan (embora presente, mas de maneira diferente em outros países) é o papel dos corretores. O termo é usado para denominar agências de emprego no país que fazem a mediação entre empregadores, agências estrangeiras de recrutamento e migrantes. Com a permissão de uma intervenção de corretores, foi adicionado mais um mediador no processo de recrutamento e aumentou o custo da migração. O resultado é que trabalhadores já começam sua migração com uma dívida e ficam presos à sua condição atual de trabalho até que essa seja paga.

\section{e. O Sistema de Permissão de Emprego da Coreia do Sul}

Com uma rápida expansão econômica e precisando de trabalhadores, a Coreia do Sul resistiu recorrer à migração laboral por certo tempo. Inicialmente ela seguiu o exemplo do Japão e estabeleceu um sistema de estágio, com a intenção de preparar imigrantes para trabalhar em companhias coreanas que operavam em outros países. Na realidade, estagiários recebiam um salário de acordo com sua categoria, mas trabalhavam como empregados. Além disso, as perspectivas de emprego ao retornar ao país de origem não se materializavam. Assim, muitos deixavam seus estágios e encontravam trabalho irregular em pequenas e médias empresas. Finalmente, as disputas entre o Departamento do Trabalho (contra a implementação de políticas migratórias) e o Departamento da Indústria (a favor disso) foram resolvidas. E a Coreia do Sul adotou, em 2003, o Sistema de Permissão de Emprego (EPS, em inglês), que se diferencia de todos os outros modelos de migração temporária pois funciona com base em acordos entre governos, evitando a intermediação de 
agências de recrutamento. Com o EPS, trabalhadores de países com os quais a Coreia do Sul tem um Memorando de Entendimento podem se registrar, indicando suas qualificações e habilidades, e empregadores registram vagas que não conseguem preencher com trabalhadores locais. Quando um se alinha ao outro, trabalhadores imigrantes têm que passar por um teste linguístico, para provar conhecimento suficiente do idioma coreano. Eles são contratados por 4 anos e 10 meses, e só podem renovar o contrato uma vez. Se ao final do contrato não voltarem ao país de origem, a Coreia do Sul pode retaliar contratando menos trabalhadores daquele país. Ao final de 2013, havia 547.590 imigrantes trabalhando na Coreia do Sul, dos quais 203.473 eram chineses de etnia coreana.

\section{Similaridades e falhas da migração laboral temporária na Ásia}

Apesar das diferenças consideráveis nos diversos modelos, a recorrência à migração laboral temporária cresceu nos últimos anos. De acordo com estatísticas da OIT Organização Internacional do Trabalho, havia 105 milhões de trabalhadores migrantes em 2012, dos quais 30 milhões estavam na Ásia. Os países do Golfo tentaram diversas vezes diminuir sua dependência do trabalhador migrante, mas sem sucesso. As políticas de Cingapura e Taiwan permitem cada vez mais imigrantes e por períodos mais extensos. Na Malásia e Tailândia, as tentativas de diminuir a irregularidade também falharam e novos regulamentos são implementados de tempos em tempos. Países de origem como as Filipinas mostram um constante crescimento no envio de trabalhadores. De fato, 1.435.166 trabalhadores foram enviados em 2012 (embora dois terços desses tenham sido renovações de contratos). O crescimento contínuo da migração laboral pode indicar um fracasso de políticas migratórias restritivas. Na verdade, podemos dizer que a migração laboral se adapta às demandas de mercado e tenta maximizar os benefícios que esse movimento gera. Consequentemente, muitos falam de um cenário de ganho triplo com a migração laboral temporária.

\section{a. Maximização de benefícios para o país de destino}

Abella (2006, p. 21-22) indicou que os principais benefícios para os países de destino são de natureza econômica e inclui, entre outras coisas, a flexibilidade do mercado de trabalho, apoio para o déficit de mão de obra em algumas indústrias e fortalecimento de sua competitividade. Esses e outros benefícios econômicos se baseiam nas economias que o trabalho migrante gera: na educação e treinamento do profissional, nos benefícios sociais que a população local teria como trabalhadores e nos benefícios de longo prazo por não se estabelecerem, sozinhos ou com família, no país. Evidentemente que o objetivo do país receptor é tirar benefícios econômicos 
da situação. Migrantes são considerados trabalhadores e não como pessoas que poderiam contribuir para vida social e cultural no país. No nível social o migrante é visto como problema. Consequentemente, manter a migração temporária é crucial.

\section{b. Maximização dos benefícios econômicos para o país de origem}

O país de origem também prefere a migração laboral temporária pois, igualmente, essa maximiza seus benefícios. Uma lista básica das vantagens inclui: menor taxa de desemprego, mais recebimento de remessas de dinheiro, e trabalhadores com novas habilidades adquiridas no exterior. Não existe consenso sobre se a migração temporária de fato traz esses benefícios. No entanto, a remessa de dinheiro é algo concreto e é um dos principais fatores que vinculam a migração ao desenvolvimento. Novamente, nenhum benefício social é considerado nos resultados, talvez porque não se preveja nenhuma vantagem social nesse quadro. Quanto ao custo social para o país de origem, ele só poderá ser observado depois de anos, porém essas políticas normalmente focam em objetivos de curto prazo. Além disso, mesmo para países de origem a temporariedade é crucial, pois os custos sociais da migração são minímos se o trabalhador só se ausenta de casa por um curto tempo. A migração permanente - com uma perda permanente de população e a erosão das remessas de dinheiro - é considerada mais prejudicial.

\section{c. Maximização dos benefícios econômicos para o migrante trabalhador}

A migração temporária traz benefícios para o trabalhador. Para todos, mas especialmente para os menos qualificados, a migração é um modo de conseguir salários mais altos. Existem outras motivações na experiência migratória (melhorias profissionais e avanços na carreira, para os mais qualificados, novas experiências em outro país, para os jovens, e motivos familiares para outros), mas a melhoria econômica é o principal objetivo. Experiência de trabalho, maturidade, enriquecimento cultural e às vezes até uma experiência religiosa profunda podem ser benefícios adquiridos em uma experiência bem sucedida. Ainda assim, a migração temporária tem alguns custos: rompimentos familiares, distanciamento dos filhos, desencantamento próprio, problemas físicos e psicológicos, dificuldade de se reinserir no retorno para casa. Para o migrante, a temporariedade do projeto não é necessariamente crucial para conseguir o máximo de seus objetivos. O migrante deveria ser capaz de escolher a duração de sua empreitada.

Como o ganho triplo associado à migração laboral temporária não é incontestável e, na verdade, ela está cheia de abusos e violações, quais são as questões a serem discutidas? Essas questões são relativas ao modo como a migração temporária é gerenciada, ou seriam elas inerentes ao sistema? 


\section{Falhas no sistema migratório laboral}

Falhas na experiência histórica do sistema migratório laboral são bem conhecidas. No entanto, mesmo programas modernos continuam a mostrar características problemáticas devido aos custos econômicos, sociais e psicológicos impostos aos imigrantes e à atuação descontrolada dos intermediários, bem como as irregularidades que travam o sistema.

A primeira falha nesse sistema é a incerteza de que a migração temporária continuará temporária. O motivo principal disso é que países de destino tentam suprir uma demanda permanente de trabalhadores com migrantes temporários. Eventualmente, empregadores acham mais fácil manter o trabalhador atual e não treinar novos imigrantes. A atualização constante do limite de estadia para Taiwan (originalmente 3 anos, mas atualmente 12) é um ótimo exemplo disso. Também temos o número crescente de trabalhadores que renovam seus contratos (dois terços dos que deixam as Filipinas todo ano) a indicar o mesmo problema. A temporariedade estrita não é praticável.

No entanto, chegou-se uma combinação do temporário com o permanente na Ásia: os migrantes são economicamente permanentes, dado que renovam seus contratos e continuam na mesma empresa, mas sendo legalmente temporários não podem acumular tempo de estadia para se tornarem residentes permanentes ou ganhar benefícios sociais. A migração temporária traz benefícios de curto prazo para o trabalhador, com seu salário mais alto, mas perdas a longo prazo, dado que não provê seu bem-estar social nem direitos de pensão.

Um forte elemento no insucesso da política de migração temporária em manter a migração como "temporária" na Europa foi a reunificação familiar. No contexto dos países europeus, a reunificação não poderia ser negada, já que era garantida pela Carta Social do Conselho Europeu. A Ásia resistiu à garantia de reagrupamento aos migrantes laborais, pois eles não teriam condições físicas de morar com suas famílias (a maior parte fica em campos de trabalho), e também porque países de destino não querem arcar com os custos sociais relacionados à famílias e ao estabelecimento de imigrantes em seu interior. Evitar a reunificação é provavelmente o principal motivo do sucesso da temporariedade da migração na Ásia. O custo pago pelos migrantes é expresso na solidão e isolamento nos quais vivem e que, em alguns casos, dificultam a criação dos filhos e causam separações familiares.

O segundo problema é o interesse limitado em lidar com os papéis dos intermediários (agenciadores). Intermediários são muito usados em migrações internacionais hoje em dia. O que costumava ser controlado tradicionalmente pelo governo, hoje em dia é gerenciado pelo setor privado. $O$ interesse desse último em aumentar o envio de pessoas anda lado a lado com o interesse governamental em aumentar as remessas de dinheiro vindas do trabalho dos migrantes. Regras mais rigorosas seriam possíveis caso os governos aceitassem 
menos emigrantes e remessas de dinheiro. $O$ setor privado age com base no desejo de todas as partes interessadas pelo trabalho migrante, mesmo que regras e padrões de gerenciamento fiquem mais frouxos. Existem evidências de que países de origem podem ser mais coerentes em suas políticas (as Filipinas e a Indonésia mantiveram-se firmes e contiveram o envio de trabalhadoras domésticas para a Arábia Saudita). Entretanto, a competitividade dos países que mandam trabalhadores faz com que seja difícil impor regras padrão nas normas de recrutamento de migrantes.

Um terceiro problema refere-se aos custos da migração. De acordo com a Convenção e recomendação sobre trabalho decente para as trabalhadoras e trabalhadores domésticos, nำ189, no seu Artigo 15 que trata referente a regulamentação sobre as agências de recrutamento privadas (OIT, 2011), os migrantes não devem ser cobrados pelo recrutamento ou sua colocação no trabalho. O custo deve ser responsabilidade do empregador. Na verdade, a migração é cara, e para muitos migrantes pobres isso é pago através de empréstimos ou deduções salariais, o que prejudica seu poder de barganha caso algo dê errado. Depois que chegam ao local suas dívidas fazem com que fiquem em situações desfavoráveis. Considerando que seu emprego é temporário, os migrantes não podem perdê-lo, e sua autonomia é limitada.

A migração na Ásia também é caracterizada pela presença de migrantes irregulares. A migração irregular é uma realidade em todos os sistemas migratórios e está relacionada à proximidade geográfica dos países e suas diferentes condições socioeconômicas. Contudo, no sistema migratório laboral temporário a irregularidade acontece em todas as fases: recrutamento, admissão e emprego. É uma consequência de políticas incoerentes e não realistas. A falta de realismo e coerência estão presentes nos países de origem ao formularem políticas ideais que não podem ser implementadas por conta da alta demanda de trabalhadores no estrangeiro, ou que exigem condições que o mercado não está disposto a oferecer. Recrutadores acabam contornando facilmente as regras, e os migrantes estão dispostos a abrir mão da proteção social pela certeza de um emprego. Elas também estão presentes nos países de destino, que preveem metas irrealistas de admissão, ignoram a situação nas quais os migrantes vivem e trabalham. E também impedem a criação de um projeto de vida quando a migração fica restrita a temporariedade.

Em geral, o cenário de ganho triplo associado à migração temporária não reflete o mesmo nível de ganho para todos. Não só os imigrantes ganham menos, eles também pagam o preço pelo ganho dos outros. Embora isso seja característico de toda relação laboral, é particularmente enfatizado no sistema de migração laboral.

Para abordar essas problemáticas inerentes à migração laboral temporária, os EUA resolveram parar completamente com esse tipo de migração, e a Europa mudou suas políticas. No entanto, ela continua e é motivada pelo 
desenvolvimento que gera e pode ser organizada para se evitar os problemas passados. Esta é a posição de pesquisadores e governos que dizem que a migração laboral vai funcionar se der certo para todas as partes envolvidas. Isso requer o preenchimento de três condições pré-existentes: "acesso ao mercado formal de trabalho; proteção e empoderamento dos migrantes; e uma certa garantia de temporariedade" (GFMD - Global Forum on Migration and Development 2007,5 ). Nós já indicamos que a migração laboral não funciona para todos do mesmo modo. Além disso, a demanda de migrantes é gerada pelo mercado informal e a garantia de temporariedade é disfarçada pela renovação de contratos de curta duração. A próxima sessão desse texto abordará a problemática da proteção e empoderamento.

\section{Uma migração baseada em direitos humanos}

A convicção de que um sistema migratório efetivo deve se basear no reconhecimento e respeito pelos direitos humanos ganhou chão no diálogo internacional. Isto é repetido em todas as reuniões internacionais e foi detalhado no "Quadro Multilateral sobre Migração Laboral" (OIT, 2006). Uma abordagem baseada em direitos humanos se torna necessária pois a migração, especialmente a laboral temporária, deixa o migrante vulnerável, uma vez que ele passa a ser um simples executor de trabalho; torna-se um peso ao sistema de bem-estar social; transforma-se em um estranho e um criminoso em potencial. Em vez disso, a base no direito humano prioriza o direito à dignidade dos migrantes, reconhece que sua identidade vai além da sua condição migratória e limita o poder do Estado sobre eles, mesmo os irregulares. A questão a ser levantada sobre essa abordagem é se eles têm proteção legal o suficiente e o que fazer para melhorar isso.

\section{a. Instrumentos para a proteção dos direitos dos migrantes}

Paradoxalmente, os migrantes têm muitos instrumentos para defender seus direitos, mas pouca proteção de fato. Sem entrarmos em detalhes, eles são protegidos por todos os instrumentos de direitos humanos - a não ser que seja determinado o contrário - e por tratados regionais; pelas principais convenções da OIT e, especificamente, pela Convenção de Migração para Trabalho (Revisada) (97) de 1949, e pela Convenção sobre os Trabalhadores Migrantes (Disposições Complementares) (143) de 1975. Mesmo a categoria menos protegida de migrantes, os trabalhadores domésticos, agora têm um instrumento internacional de proteção, a Convenção 189 da OIT. Finalmente, a Convenção Internacional para a Proteção dos Direitos de Todos os Trabalhadores Migrantes e Membros de suas Famílias (MWC, em inglês) ilustra extensivamente os direitos dos migrantes.

Com tantas ferramentas, quais são os motivos para a falta de proteção? 
Porque esses instrumentos para a proteção dos migrantes estão entre os menos ratificados? A convenção 97 foi ratificada por 47 países; a convenção 143 por 23; e a MWC teve 37 ratificações.

Quais são os motivos da falta de ratificação? Em alguns casos existem obstáculos técnicos, disposições que os governos não gostam, como a que garantiria tratamento igual entre migrantes e cidadãos nacionais (art. 6 da Convenção 97 e art. 10 da Convenção 143), ou a que garante proteção caso ele perca seu emprego (srt. 8 da Convenção 143), e até o desentendimento comunicativo, como o medo de que a MWC possa ditar política de admissão, o que na verdade ela não faz. Em outros casos existem dificuldades técnicas, como falta de experiência em lidar com o gerenciamento da migração. A maior parte dos problemas é de cunho político, especificamente não querer se amarrar à normas sobre um assunto que é mais valorizado quanto menos regulamentos tiver. Nesse sentido, pode-se dizer que quanto menos proteção é garantida aos trabalhadores migrantes, mais cresce o valor da migração temporária. Assim, qual seria a melhor abordagem para garantir que esses migrantes serão protegidos?

\section{b. Em direção a uma melhor proteção dos migrantes}

O melhor amparo ao migrante vem de legislações nacionais. Elas podem proteger bem, mesmo sem o país ter assinado os instrumentos internacionais relevantes ao assunto. Por outro lado, legitimar esses documentos gera um quadro mais favorável para a legislação nacional. Nesse ponto, ainda é relevante incentivar a ratificação de convenções internacionais.

Como visto nas discussões anteriores, a proteção ao trabalhador migrante não vem de graça. Ela deve ser conquistada através de negociações. O nível mais relevante de negociação é de país para país. Os acordos bilaterais têm recebido mais atenção nas duas últimas décadas, e até os países do Golfo têm assinado acordos com os países de origem. Frequentemente esses são mais focados em facilitar o emprego e menos em proteção ao trabalhador (Batistella, 2012). Ainda assim, isso é um progresso em relação à abordagem de políticas unilaterais.

A proteção aumenta também se os migrantes têm acesso aos mecanismos de justiça, como cortes e outros instrumentos de arbitragem. Infelizmente, acesso ao sistema legal do país de destino é bem difícil para os migrantes, principalmente porque os processos podem ser longos e caros. A responsabilidade conjunta e solidária entre recrutadores e empregadores nas Filipinas oferece aos migrantes a possibilidade de conseguir justiça mesmo depois de repatriado, já que os recrutadores são responsáveis pelo tratamento dado aos trabalhadores enquanto estão em outro país. A princípio é uma boa ideia, mas é difícil que os julgamentos sejam favoráveis ao migrante. 
Migrantes normalmente não podem se juntar a um sindicato, e muito menos formar um. Por esse motivo, acordos internacionais entre sindicatos para oferecer proteção aos cidadãos de países recíprocos são considerados como progresso. Contudo, muito mais pode ser feito para empoderar os migrantes tornando-os capazes de negociar sua própria situação.

Alguns autores argumentam que aumentar a proteção dos trabalhadores migrantes pode não ser tão interessante para os países de origem, ou mesmo para os migrantes. Pois, os países de destino podem diminuir o número de trabalhadores aceitos para aumentar a proteção (Ruhs e Martin 2006). Recentemente (Ruhs, 2013) argumentou que uma abordagem baseada estritamente em direitos deve dar lugar a outra na qual se possa discutir quais diretos devem ser protegidos e quais podem ser suprimidos.

Em minha opinião, o debate deveria determinar alguns pontos permanentes. Primeiramente, deveria haver um nível de proteção aos migrantes que fosse não negociável. A proteção dos direitos fundamentais e da dignidade deve ser inquestionável, independente do número de migrantes aceitos no país. Se a garantia dos direitos fundamentais não for aceitável, então não deve haver migração no país.

Em segundo lugar, se o nível de proteção garantido estiver abaixo dos padrões internacionais, a determinação desse nível não deveria ficar unicamente nas mãos de empresas e do governo do país de destino. Acordos entre países de origem sobre condições básicas de trabalho continuam sendo necessárias. Assim, "todas as partes interessadas devem se juntar nessa tarefa" (IOM, 2005, p. 71).

Além disso, se a negociação por um nível menor de proteção é motivada pela maximização de lucros da empresa contratante, esse objetivo deve ser contestado, pois não há limite para essa vontade de lucrar. Mais uma vez vemos a necessidade de mais autonomia para os migrantes, para que possam defender o que é importante para eles.

Por fim, voltamos ao mesmo assunto básico: que a baixa proteção ao trabalhador migrante é inerente ao sistema, apesar de suas diferenças regionais. Para trabalhadores de baixa qualificação, quanto mais temporário o programa, menor a proteção. A recomendação de organizações internacionais para migração com proteção adequada parece ilusória frente aos fatos reais. A única solução parece ser organizar a migração temporária para que ela possa ser estendida pelo migrante conforme suas necessidades. A duração e estabelecimento do indivíduo deve vir acompanhada da progressão adequada de seus direitos. 


\section{Notas:}

1 - "Livro Branco da População" - documento organizado pelo Governo de Cingapura para sistematizar e avaliar a articulação entre população e desenvolvimento do pais. A edição citada pelo autor tem como título: "A sustainable population for a dynamics Singapore Population White Paper". (Nota do Editor)

\section{Referências}

ABELA, Manolo. Policies and best practices for management of temporary migration. International Symposium on International Migration and Development. Turin, 28-30 June 2006.

BADE, Klaus J. Migration in European History. Malden, MA: Blackwell, 2003.

BATTISTELLA, Graziano. Multi-level Policy Approach in the Governance of Labour Migration: Considerations From the Philippine Experience. Asian Journal of Social Science 40 (2012) 419-446.

BOBEVA, Daniela; GARSON, Jean-Pierre. Overview of Bilateral Agreements and Other Forms of Labour Recruitment. In. OECD - Organization for Economic Cooperation and Development. Migration for Employment Bilateral Agreements at a Crossroad. Paris: OECD, 2004.

CANADA. Immigration. Canada, 2013.

Disponível em: www.cic.gc.ca

CASTLES, Stephen. Guestworkers in Europe: a resurrection? International Migration Review, Vol. 40, N. 4, 2006.

CHEANG, Sopheng. Number of Cambodian workers leaving under pressure from Thailand tops 160,000. Star Tribune, June 16, 2014.

DIBP - Department of Immigration and Border Protection. Immigration. Australia, 2013. Disponível em: http://www.border.gov.au/

EUA - ESTADOS UNIDOS DA AMÉRICA. Homeland security. EUA, 2012.

Disponível em: www.dhs.gov

GCIM - Global Commission on International Migration. Migration in an Interconnected World: New Directions for Action. Report of the Global Commission on International Migration. CGIM, New York, 2005.

GFMD - Global Forum on Migration \& Development. Temporary labor migration as a contribution to development: sharing responsibility. Background Paper. GFMD, Brussels 9-11 July 2007.

IOM - International Organization for Migration. Labour Migration in Asia: Protection of Migrant Workers, Support Services and Enhancing Development Benefits. IOM: Geneva, 2005. 
KAPISZEWSKI, Andrzej. Arab versus Asian Migrant Workers in the GCC Countries. United Nations Population Division. UN/POP/EGM/2006/02.

LEVINSON, Amanda. The Regularisation of Unauthorized Migrants: Literature Survey and Country Case Studies. Centre on Migration, Policy and Society, University of Oxford, 2005.

MARTIN, Philips. Promise Unfulfilled: Unions, Immigration and Farm Workers. Ithaca, NY: Cornell University Press, 2003.

McLOUGHLIN, Sheena; MÜNZ, Rainer. Temporary and circular migration: opportunities and challenges. European Policy Center, Working Paper N. 35, March 2011.

OIT - ORGANIZAÇÃO INTERNACIONAL DO TRABALHO. Convenção e recomendação sobre trabalho decente para as trabalhadoras e trabalhadores domésticos (Convenção no189). OIT: Genebra, 2011. Disponível em: http://www.oit.org.br/sites/default/files/topic/ housework/doc/nota_5_convencao_recomendacao_450.pdf

OIT - ORGANIZAÇÃO INTERNACIONAL DO TRABALHO. Convenção 97- Sobre os trabalhadores migrantes (Revisada). OIT: Genebra, 1949.

OIT - ORGANIZAÇÃO INTERNACIONAL DO TRABALHO. Multilateral Framework on Labour Migration Non-binding principles and guidelines for a rights-based approach to labour migration. OIT: Geneva, 2006

PLEWA, Piotr; MILLER, Mark J. Postwar and Post-Cold War Generations of European Temporary Foreign Worker Policies: Implications for Spain. Migraciones Internacionales, 3 (2) 2005.

RUHS, Martin. The potential of temporary migration programs in future international migration policies. Geneva: Global Commission on International Migration, September, UN, 2005.

RUHS, Martin. The Price of Rights. Regulating International Labor Migration, Princeton, NJ: Princeton University Press, 2013.

RUHS, Martin; MARTIN, Philip. Numbers vs. Rights: Trade-offs and Guest workers programmes. University of Oxford, Centre on Migration, Policy and Society, WP 40, 2006.

SINGAPORE. National Population and Talent Division, A Sustainable Population for a Dynamic Singapore. Population White Paper. Singapore, 2013a.

SAUDI ARABIA. Royal Decree 51 of 2013. SAUDI ARABIA, 2013.

SINGAPORE. A sustainable population for a dynamics Singapore - Population White Paper. Singapore, 2013.

UM-DESA - United Nations, Departments of Economic and Social Affairs. International Migration 2013, New York 2013. 


\title{
RESUMO:
}

Países tradicionais de imigração buscam políticas de migração permanente e concedem, todo ano, certo número de vistos para a residência permanente. Os procedimentos para concessão de vistos, os requerimentos para obtê-los e a sua distribuição variam de país para país. Mas, o objetivo comum é permitir que imigrantes residam em seus territórios. Contudo, na verdade, todos os países têm algum modelo de migração temporária. Esse tipo de movimento tem recebido muita atenção nos últimos 10 a 15 anos. Trata-se de um interesse que lança novas questões sobre as vantagens e desvantagens da migração laboral, sua sustentabilidade e a possibilidade de uma abordagem da migração temporária baseada em direitos. Esse artigo irá examinar experiências históricas de migração temporária e sua recente volta. Também analisará esse movimento na Ásia, concernindo seus quatro modelos diferentes e incluindo suas vantagens e desvantagens. $\mathrm{O}$ artigo será concluído apontando elementos para uma abordagem da questão migratória baseada em direitos.

Palavras chaves: migração temporária, trabalho, políticas migratórias

\begin{abstract}
:
Traditional countries of immigration are seeking permanent migration policies and grant every year, a certain number of visas for permanent residence. The procedures for issuing visas, applications to get them and the distribution of these vary from country to country. But the common goal is to enable immigrants residing in their territories. However, in reality, all countries have some temporary migration model. This type of movement has received much attention in the last 10-15 years. This new interest raises new questions about the advantages and disadvantages of labor migration, its sustainability and the possibility of a temporary migration approach based on rights. This article will examine historical experiences of temporary migration and its recent back. Also examine this movement in Asia, concernindo its four different models and including their advantages and disadvantages. The article will conclude by pointing elements for an approach to the migration issue rights-based.
\end{abstract}

Key words: temporary migration, labor, migration policies 